\title{
THE LUNG VOLUME IN LOW OUTPUT CARDIAC SYNDROMES
}

BY

\author{
D. G. B. RICHARDS, A. G. W. WHITFIELD, W. M. ARNOTT, AND J. A. H. WATERHOUSE
}

From the Departments of Medicine and Medical Statistics, Queen Elizabeth Hospital, University of Birmingham

Received May 2, 1951

During the past four years lung volume studies have been carried out in this department on a large series of normal subjects and on many victims of cardiac and respiratory disease. Some findings have been published elsewhere (Whitfield, Waterhouse, and Arnott, 1950a, b, and $c$ ) and this paper concerns the results obtained in patients with low output cardiac syndromes.

The lung volume in heart disease has been studied by several workers but their results have been to some extent at variance and were obtained before simple methods of measuring cardiac output were available. Over 30 years ago Peabody and Wentworth (1917) found the vital capacity to be decreased below 90 per cent of normal (predicted from the surface area) in 131 of their 156 unspecified cardiacs. The shrinkage in vital capacity was greatest in the decompensated patients and their working capacity and expectation of life decreased in proportion to the fall in their vital capacity. McClure and Peabody (1917) in a study of 24 patients with " heart disease" confirmed that the vital capacity decreased with the degree of congestive failure and increased again as the patients came out of failure, returning to normal only if full compensation was restored. Brittingham and White (1922) reached exactly similar conclusions from a study of 48 patients with " heart disease." Pearce (1917) reported one case of decompensated heart disease in which the vital capacity diminished as the cardiac output fell. Peters and Barr (1921) determined all the divisions of lung volume in six patients with " heart disease" and compared the results obtained with the predicted volumes, using Lundsgaard's three-dimensional chest measurements for the purpose of prediction. Of the 6 patients, 5 who were decompensated showed diminished total lung volumes and vital capacities; in 3 of the 5 the residual air was reduced and in the other 2 it was normal. The one compensated case showed a slightly reduced total lung volume and vital capacity and a normal residual air. Lundsgaard (1923) in a study of 11 cases of "heart disease" ( 3 decompensated and 8 compensated) found the vital capacity decreased in all, especially those in failure; the total lung volume and residual air were also decreased in the decompensated cases but the residual air was substantially increased in those not in failure. Binger (1923) used West's surface-area formula for the vital capacity and from it predicted the other lung volume divisions. In 11 cases of rheumatic heart disease, dyspnœic on the slightest exertion but not in actual failure, he found the vital capacity diminished and the residual air increased, but when decompensation supervened the vital capacity further diminished but the residual air sometimes became greater and sometimes less. Meakins and Christie (1929) confirmed the correlation between the reduction in vital capacity and the degree of dyspnœa and also found a virtual disappearance of the reserve air and an increase in the residual air/total lung volume ratio in heart failure, the latter increasing and decreasing pari passu with the degree of decompensation. Altschule et al. (1943) studied the postural changes in lung volume in low output cardiacs and found them similar to those occurring in normal subjects.

\section{Methods}

Studies were made of 26 patients suffering from rheumatic heart disease, hypertension, or coronary artery disease. They were first assessed clinically and radiologically, and then grouped for statistical purposes according to their state of compensation. The first group comprised 8 cases all well compensated and with a normal or moderately reduced exercise tolerance (i.e. Grade I and II). In the second group were 8 patients who were dyspnoic on the slightest exertion but showed no other objective evidence of congestive cardiac failure (grade III). The third group of the remaining ten cases were in congestive failure (grade IV). Fuller details of each group are given in Table I. With patients in the sitting position the vital 
capacity, complemental air, and reserve air were measured on a Benedict-Knipping spirometer in the usual way and the functional residual air was determined by the closed circuit constant volume hydrogen (or helium) dilution method described by McMichael (1939). The residual air was obtained by subtracting the reserve air from the functional residual air.

TABLE I -

Sex, Age, and Aetiological Distribution

\begin{tabular}{|c|c|c|c|c|c|c|c|}
\hline \multirow{2}{*}{$\begin{array}{c}\text { State of } \\
\text { Compensation }\end{array}$} & \multirow{2}{*}{ No. } & \multicolumn{2}{|c|}{ Age (years) } & \multirow{2}{*}{ Sex } & \multirow{2}{*}{$\begin{array}{l}\text { Rheumatic } \\
\text { Disease }\end{array}$} & \multirow{2}{*}{$\begin{array}{l}\text { Hyper- } \\
\text { tension }\end{array}$} & \multirow{2}{*}{$\begin{array}{c}\text { Coronary } \\
\text { Disease }\end{array}$} \\
\hline & & Mean & Range & & & & \\
\hline Grade I or II & 8 & $27 \cdot 3$ & $15-46$ & $3 \mathrm{M}, 5 \mathrm{~F}$ & 7 & 1 & - \\
\hline Grade III & 8 & $39 \cdot 3$ & $19-55$ & $3 \mathrm{M}, 5 \mathrm{~F}$ & 4 & 2 & 2 \\
\hline Grade IV & 10 & $41 \cdot 7$ & $13-66$ & $5 \mathrm{M}, 5 \mathrm{~F}$ & 5 & 2 & 3 \\
\hline
\end{tabular}

\section{RESULTS}

In a previous communication (Whitfield et al., 1950c) the correlation in normal subjects between the lung volume and age, height, weight, chest expansion and radiological chest volume was reported and multiple regression equations by which the total lung volume and its subdivisions could be predicted from these five variables were given. In congestive cardiac failure the radiological chest volume is likely to be reduced by ascitic fluid and hepatic engorgement producing upward displacement of the diaphragm, and dyspnœa will often prevent full chest expansion. In this series of cases we have therefore only considered age, height and weight and from these have predicted what the lung volume would have been had they been normal subjects. The predicted absolute values thus obtained and the actual results of spirometry are shown for each of the three groups in Table II.

TABLE II

Predicted and Observed Absolute Lung Volumes

\begin{tabular}{|c|c|c|c|c|c|c|c|c|c|c|c|c|}
\hline \multirow[b]{2}{*}{ Group } & \multirow[b]{2}{*}{$\begin{array}{c}\text { Division of } \\
\text { Lung } \\
\text { Volume }\end{array}$} & \multicolumn{3}{|c|}{ Males } & \multicolumn{3}{|c|}{ Females } & \multicolumn{5}{|c|}{ Males and Females } \\
\hline & & $\begin{array}{l}\text { पूँ } \\
\text { 岕 } \\
0 \\
0\end{array}$ & 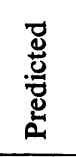 & 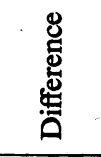 & $\begin{array}{l}\text { 范 } \\
\text { o. } \\
0\end{array}$ & 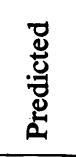 & 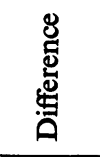 & $\begin{array}{l}\text { Jँ } \\
\text { 总 } \\
0\end{array}$ & 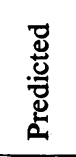 & 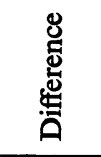 & $\begin{array}{l}\text { S.E. } \\
\text { of } \\
\text { Mean }\end{array}$ & p \\
\hline $\begin{array}{c}\text { Grade } \\
\text { I and II } \\
\text { cardiacs } \\
3 \mathrm{M}, 5 \mathrm{~F}\end{array}$ & $\begin{array}{ll}\text { T.L.V. } & \quad \\
\text { V.C. } & \quad \\
\text { C.A. } & \quad \\
\text { R.A. } & \quad \therefore \\
\text { F.R.A. } \\
\text { Resid. } \\
\text { Air }\end{array}$ & $\begin{array}{l}6 \cdot 38 \\
4 \cdot 12 \\
2 \cdot 42 \\
1 \cdot 71 \\
3 \cdot 96 \\
2 \cdot 26\end{array}$ & $\begin{array}{l}6 \cdot 09 \\
4 \cdot 37 \\
3 \cdot 01 \\
1 \cdot 36 \\
3 \cdot 08 \\
1 \cdot 72\end{array}$ & $\begin{array}{l}+0.29 \\
-0.25 \\
-0.59 \\
+0.35 \\
+0.88 \\
+0.54\end{array}$ & $\begin{array}{l}4.95 \\
3.10 \\
1.99 \\
1.11 \\
2.96 \\
1.84\end{array}$ & $\begin{array}{l}4 \cdot 69 \\
3 \cdot 22 \\
2 \cdot 19 \\
1 \cdot 02 \\
2 \cdot 49 \\
1 \cdot 47\end{array}$ & $\begin{array}{l}+0.26 \\
-0.12 \\
-0.20 \\
+0.09 \\
+0.47 \\
+0.37\end{array}$ & $\begin{array}{l}5 \cdot 48 \\
3 \cdot 49 \\
2 \cdot 15 \\
1 \cdot 34 \\
3 \cdot 33 \\
2 \cdot 00\end{array}$ & $\begin{array}{l}5.21 \\
3.65 \\
2.50 \\
1.15 \\
2.71 \\
1.56\end{array}$ & $\begin{array}{l}+0.27 \\
-0.16 \\
-0.35 \\
+0.19 \\
+0.62 \\
+0.44\end{array}$ & $\begin{array}{l}0 \cdot 23 \\
0 \cdot 18 \\
0 \cdot 13 \\
0 \cdot 13 \\
0 \cdot 19 \\
0 \cdot 16\end{array}$ & $\begin{array}{l}0.25 \\
0.37 \\
0.005 \\
0.13 \\
0.001 \\
0.001\end{array}$ \\
\hline $\begin{array}{l}\text { Grade } \\
\text { III } \\
\text { cardiacs } \\
3 \mathrm{M}, 5 \mathrm{~F}\end{array}$ & $\begin{array}{lr}\text { T.L.V. } & . \\
\text { V.C. } & \cdots \\
\text { C.A. } & \because \\
\text { R.A. } & \quad \cdots \\
\text { F.R.A. } & \text { Resid. Air }\end{array}$ & $\begin{array}{l}4.71 \\
2.78 \\
1.71 \\
1.07 \\
3.00 \\
1.93\end{array}$ & $\begin{array}{l}5 \cdot 68 \\
3.53 \\
2.58 \\
0.96 \\
3 \cdot 10 \\
2 \cdot 15\end{array}$ & $\begin{array}{l}-0.97 \\
-0.75 \\
-0.87 \\
+0.11 \\
-0.10 \\
-0.22\end{array}$ & $\begin{array}{l}3 \cdot 78 \\
2 \cdot 37 \\
1 \cdot 48 \\
0.89 \\
2 \cdot 29 \\
1 \cdot 40\end{array}$ & $\begin{array}{l}4.30 \\
2.97 \\
2.03 \\
0.93 \\
2.26 \\
1.33\end{array}$ & $\begin{array}{l}-0.52 \\
-0.60 \\
-0.55 \\
-0.04 \\
+0.03 \\
+0.07\end{array}$ & $\begin{array}{l}4.13 \\
2.53 \\
1.57 \\
0.96 \\
2.56 \\
1.60\end{array}$ & $\begin{array}{l}4 \cdot 82 \\
3 \cdot 18 \\
2 \cdot 24 \\
0.94 \\
2 \cdot 58 \\
1.64\end{array}$ & $\begin{array}{l}-0.69 \\
-0.65 \\
-0.67 \\
+0.02 \\
-0.02 \\
-0.04\end{array}$ & $\begin{array}{l}0 \cdot 23 \\
0 \cdot 18 \\
0 \cdot 13 \\
0 \cdot 13 \\
0 \cdot 19 \\
0 \cdot 16\end{array}$ & $\begin{array}{c}0.003 \\
0.0003 \\
<0.0001 \\
0.13 \\
0.29 \\
0.16\end{array}$ \\
\hline $\begin{array}{c}\text { In } \\
\text { Congestive } \\
\text { failure } \\
\text { Grade IV } \\
\text { cardiacs } \\
5 \mathrm{M}, 5 \mathrm{~F}\end{array}$ & $\begin{array}{ll}\text { T.L.V. } & . \\
\text { V.C. } & \because \\
\text { C.A. } & \because \\
\text { R.A. } & \quad \because \\
\text { F.R.A. } & \therefore \cdot \\
\text { Resid. Air. }\end{array}$ & $\begin{array}{l}3.14 \\
1.58 \\
1.07 \\
0.51 \\
2.07 \\
1.56\end{array}$ & $\begin{array}{l}4.76 \\
3.04 \\
2.06 \\
0.98 \\
2 \cdot 70 \\
1.72\end{array}$ & $\begin{array}{l}-1.62 \\
-1.46 \\
-0.99 \\
-0.47 \\
-0.63 \\
-0.16\end{array}$ & $\begin{array}{l}2.73 \\
1.58 \\
1.16 \\
0.42 \\
1.57 \\
1.15\end{array}$ & $\begin{array}{l}4 \cdot 16 \\
2.93 \\
2.00 \\
0.93 \\
2 \cdot 16 \\
1 \cdot 23\end{array}$ & $\begin{array}{l}-1.43 \\
-1.35 \\
-0.84 \\
-0.51 \\
-0.59 \\
-0.08\end{array}$ & $\begin{array}{l}2.94 \\
1.58 \\
1.12 \\
0.46 \\
1.82 \\
1.36\end{array}$ & $\begin{array}{l}4.46 \\
2.98 \\
2.03 \\
0.95 \\
2.43 \\
1.48\end{array}$ & $\begin{array}{l}-1.52 \\
-1.40 \\
-0.91 \\
-0.49 \\
-0.61 \\
-0.12\end{array}$ & $\begin{array}{l}0 \cdot 22 \\
0 \cdot 16 \\
0 \cdot 12 \\
0 \cdot 12 \\
0 \cdot 18 \\
0 \cdot 15\end{array}$ & \begin{tabular}{|c|c|}
$<0.0001$ \\
$<0.0001$ \\
$<0.0001$ \\
$<0.0001$ \\
0.0007 \\
0.42
\end{tabular} \\
\hline
\end{tabular}


In Grades I and II it will be seen that the most striking changes are an increase in the functional residual air and residual air and a decrease in the complemental air with a consequent elevation of the resting respiratory level. The total lung volume, vital capacity, and reserve air are not materially altered. In Grade III the functional residual air and residual air return to normal and the reserve air is again unchanged, but there is an even greater reduction in complemental air which is reflected in a highly significant reduction in the vital capacity and total lung volume.

In congestive cardiac failure there is a highly significant reduction in all divisions of lung volume except the residual air which remains the same as the predicted value. These changes are shown diagrammatically in the figure.

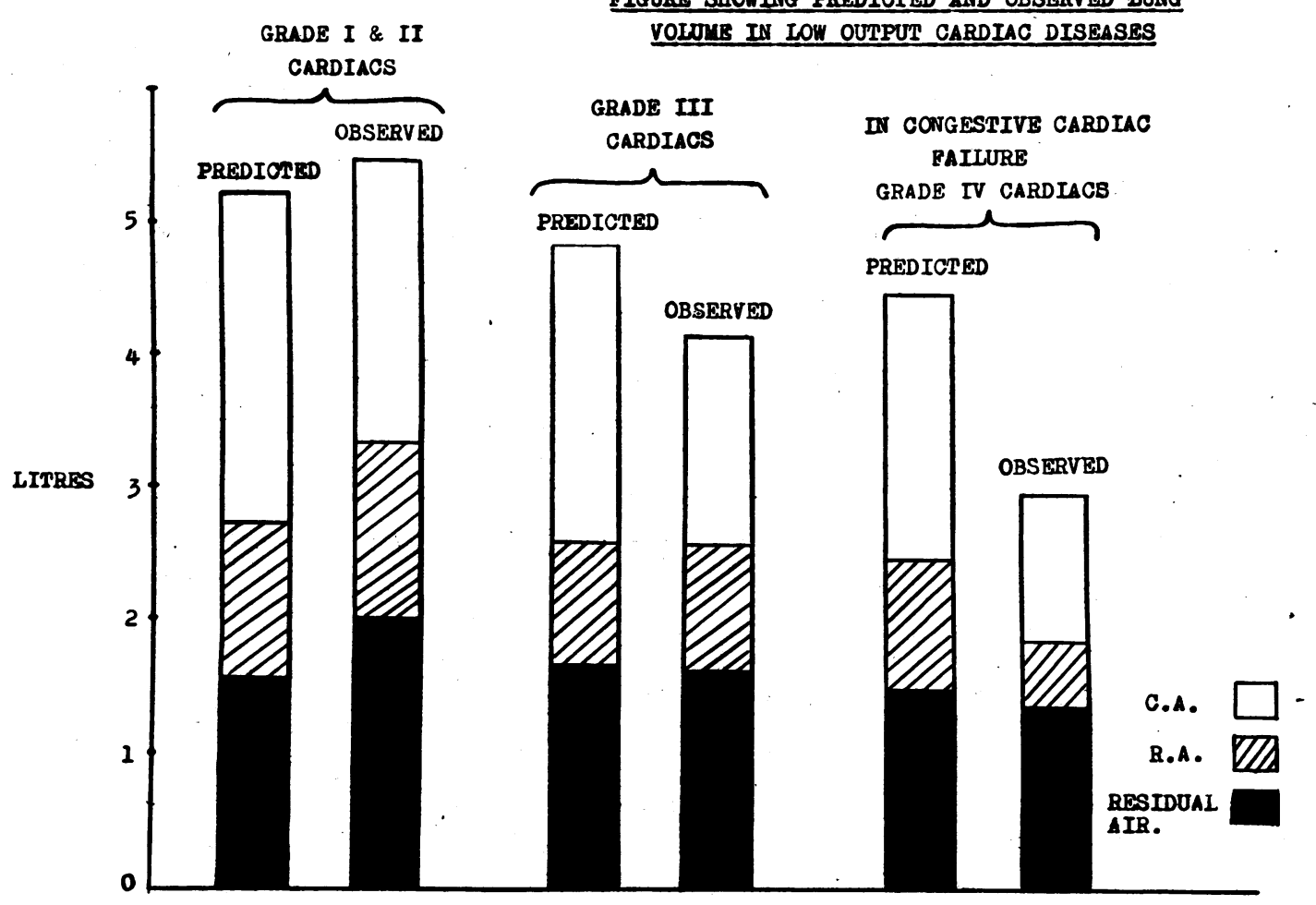

In order to amplify these findings the lung volume determination of seven patients of the third group was repeated when their degree of failure was appreciably greater or less than it had been at the time of the first measurement. The results are shown in Table III, which shows that there is a shrinkage in all divisions of lung volume (including the residual air) as the degree of cardiac failure increases. While this is in accord with the conclusions reached from study of the predicted and observed lung volumes the reduction only attains statistical significance in the case of the vital capacity, reserve air and functional residual air, owing to the small number of patients and the fact that the change in clinical state was sometimes not great.

In 4 of the 7 patients more than two lung volume determinations were made and an example is shown in Table IV which gives details in the case of a man of 66 with aortic stenosis and incompetence who was first admitted in congestive failure in February, 1950, and became fully compensated again with rest and digitalis only to be readmitted in gross failure in August, 1950, and to die a few days later. The progressive increase in all lung volume divisions as the degree of cardiac failure diminished and their gross reduction in extreme failure is very striking. The changes in the residual air volume are particularly well shown. The predicted residual air for this subject was 
TABLE III

Mran Differences in Paired Observations of Absolute lung Volume of Seven

"LOW-OUTPUT" CARDIACS RE-EXAMINED WHEN DEGREE OF FAILURE HAD CHANGED

\begin{tabular}{|c|c|c|c|}
\hline $\begin{array}{l}\text { Division of } \\
\text { Lung Volume }\end{array}$ & $\begin{array}{c}\text { Difference between Lesser } \\
\text { and Greater } \\
\text { Decompensation Values } \\
\text { (litres) }\end{array}$ & $\begin{array}{c}\text { Standard Error } \\
\text { of } \\
\text { Mean }\end{array}$ & $\mathbf{p}$ \\
\hline 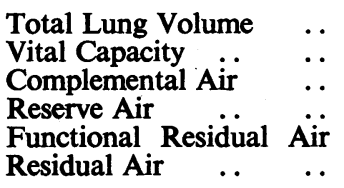 & $\begin{array}{l}0.70 \\
0.38 \\
0.18 \\
0.20 \\
0.52 \\
0.32\end{array}$ & $\begin{array}{l}0.30 \\
0.15 \\
0.13 \\
0.06 \\
0.18 \\
0.16\end{array}$ & $\begin{array}{l}0.06 \\
0.05 \\
0.21 \\
0.01 \\
0.03 \\
0.09\end{array}$ \\
\hline
\end{tabular}

TABLE IV

Lung Volume Determinations of ONe “Low-OUtPUt " Cardiac in varying degrees ó Decompensation

\begin{tabular}{|c|c|c|c|c|c|c|c|c|c|c|c|c|}
\hline \multirow[b]{2}{*}{ Date } & \multirow[b]{2}{*}{ Clinical State } & \multicolumn{6}{|c|}{ Absolute Values (litres) } & \multicolumn{5}{|c|}{ Percentage of T.L.V. Values } \\
\hline & & T.L.V. & V.C. & C.A. & R.A. & F.R.A. & $\begin{array}{l}\text { Resi- } \\
\text { dual } \\
\text { Air }\end{array}$ & V.C. & C.A. & R.A. & F.R.A. & $\begin{array}{l}\text { Resi- } \\
\text { dual } \\
\text { Air }\end{array}$ \\
\hline \multirow[t]{2}{*}{$\begin{array}{c}22 / 2 / 50 \\
6 / 3 / 50 \\
8 / 3 / 50 \\
3 / 8 / 50\end{array}$} & \multirow{2}{*}{$\begin{array}{l}\text { Gross œdema } \\
\text { Slight œdema } \\
\text { No œdema } \\
\text { Gross œdema: } \\
\text { right pleural } \\
\text { effusion }\end{array}$} & $\begin{array}{l}3 \cdot 29 \\
3 \cdot 72 \\
4 \cdot 21\end{array}$ & $\begin{array}{l}1.54 \\
1.80 \\
2.08\end{array}$ & $\begin{array}{l}1.16 \\
1.34 \\
1.43\end{array}$ & $\begin{array}{l}0.38 \\
0.46 \\
0.65\end{array}$ & $\begin{array}{l}2 \cdot 13 \\
2 \cdot 38 \\
2 \cdot 78\end{array}$ & $\begin{array}{l}1.75 \\
1.92 \\
2.13\end{array}$ & $\begin{array}{l}47 \\
48 \\
49\end{array}$ & $\begin{array}{l}35 \\
36 \\
34\end{array}$ & $\begin{array}{r}.12 \\
12 \\
15\end{array}$ & $\begin{array}{l}65 \\
64 \\
66\end{array}$ & $\begin{array}{l}53 \\
52 \\
51\end{array}$ \\
\hline & & 1.91 & 0.97 & 0.64 & 0.33 & $1 \cdot 27$ & 0.94 & 5,1 & 33 & 18 & 67 & 49 \\
\hline
\end{tabular}

1.93 litres and the observed values show an increase of $200 \mathrm{ml}$. when not in failure, a normal value in moderate failure and a reduction of one litre when failure was gross. Admittedly the right pleural effusion is an obvious factor contributing to this reduction.

It seems clear, therefore, that in compensated low output cardiac syndromes there is an elevation in the resting respiratory level, a diminution in complemental air, and an increase in functional residual air, and residual air, the remaining divisions of lung volume being unaltered. As decompensation supervenes the residual air volume returns to normal, the complemental air becomes progressively smaller and in actual failure the reserve air is also diminished. The diminution in complemental air accounts for the reduction in vital capacity and total lung volume and in failure this reduction is accentuated by the fall in reserve air which also produces diminution in the functional residual air. In failure the reduction in the various lung volume divisions becomes greater as the degree of cardiac failure increases and in severe failure the residual air is reduced to subnormal levels.

The problem is how these changes are mediated. Lundsgaard (1923) and Binger (1923) considered that the increased residual air (and the diminished vital capacity) in fully compensated heart disease is due to the increased volume of blood in the pulmonary circulation producing a "stiff lung" (Lungenstarre) with consequent inability to empty the lungs in a normal manner. That an increase in the volume of blood in the lungs would have such an effect has been demon'strated experimentally in cats by Drinker $e$ al . (1922) and in dogs by Mack et al. (1947). However, Borden et al. (1949) have shown that in compensated mitral stenosis the volume of blood in the - pulmonary vascular bed is normal, and during cardiac catheterizations we ourselves have observed a normal pressure in the smaller pulmonary arteries in cases of mitral stenosis where the right ventricular pressure has been high. The explanation of the lung volume changes in compensated 
low output cardiac syndromes therefore remains enigmatic and will probably continue so until the mechanism of the lesser circulation is better understood.

The explanation of the lung volume changes that are found in low output cardiac failure are less open to dispute. Binger (1923) considered them to arise partly from distended lung capillaries and odema encroaching on alveolar spaces (Lungenschwellung) and partly from the increased heart size and the upward displacement of the diaphragm by ascites and hepatic enlargement reducing the thoracic space available to the lungs. There seems little doubt that these are major factors and in addition the increased total blood volume in cardiac failure (Meneely and Kaltreider, 1943) and the transudation of fluid into some alveolar spaces must play a significant part. Furthermore, hydrothorax when present, will also reduce the thoracic space available for the lungs.

To ascertain the part played by heart size in the production of the lung volume changes in low output cardiac disease we have measured the cardio-thoracic ratio and also the ratio between the radiological cardiac area and the radiological chest area on the postero-anterior radiographs of 22 of our cases and have calculated their correlation with the differences between predicted and observed lung volume found in each case. The results obtained are shown in Table V. The radiological cardiac area and radiological chest area were measured with a planimeter and at least two measurements were made in each case.

TABLE V

Correlation Coefficients of Differences between Observed and Predicted Values of Lung Volume aNd Heart Size in 22 Low OutPut Cardiacs

\begin{tabular}{|c|c|c|c|c|}
\hline Division of Lung & Volume & $\cdot$ & $\begin{array}{c}\text { Cardio-Thoracic } \\
\text { Ratio }\end{array}$ & $\begin{array}{l}\text { Radiological Cardiac } \\
\text { Area-Radiological } \\
\text { Chest Area Ratio }\end{array}$ \\
\hline $\begin{array}{ll}\text { Total Lung Volume } & \ldots \\
\text { Vital Capacity } & \ldots \\
\text { Complemental Air } & \ldots \\
\text { Reserve Air } \\
\text { Functional Residual Är } \\
\text { Residual Air .. } \\
\end{array}$ & $\begin{array}{l}. . \\
\because \\
\because \\
. \\
.\end{array}$ & $\begin{array}{l}. . \\
. \\
. \\
. \\
. \\
.\end{array}$ & $\begin{array}{l}-0.694 \\
-0.647 \\
-0.515 \\
-0.571 \\
-0.606 \\
-0.453\end{array}$ & $\begin{array}{l}-0.794 \\
-0.676 \\
-0.462 \\
-0.666 \\
-0.752 \\
-0.593\end{array}$ \\
\hline
\end{tabular}

Significance levels $(n=32: 0.4237=5 \% ; 0.492=2 \% ;$ and $0.537=1 \%$

It will be seen that the differences between the observed and predicted values of all the divisions of lung volume show a significant negative correlation with both the cardio-thoracic ratio and the radiological cardiac area/radiological chest area ratio. In all but three instances the degree of correlation is high $(\mathrm{p}=<0.01)$. This means that as the maximum transverse diameter of the heart increases relative to the maximum transverse diameter of the thorax and as the proportion of the radiological chest area occupied by the heart increases so the various divisions of lung volume become increasingly lower than their predicted values. In other words the size of the heart is significantly correlated with, and probably an important factor in the production of the lung volume changes found in low output cardiac disease. The correlation coefficients, however, do not suggest that the burden of increased heart size is borne by any particular fraction of lung volume but rather that it operates, as would be anticipated, by reducing the thoracic space available to the lungs.

\section{SUMMARY}

The total lung volume and all its subdivisions have been determined in 26 "low output" cardiac patients in varying degrees of compensation. Predicted values have also been calculated from age, height, and weight.

Fully compensated cases show an increase in functional residual air and residual air, a decrease C 
in complemental air, and an elevation of the resting respiratory level. The cause of these changes is uncertain and the hypothesis of "Lungenstarre" involves dubious assumptions and is open to question.

As failure supervenes the complemental air further diminishes and the reserve air becomes less than normal; the functional residual air shrinks to subnormal levels and in extreme failure the volume of residual air is reduced. These changes result in marked diminution of the vital capacity and total lung volume.

Increased heart size is an important factor in the production of these changes and operates by reducing the thoracic space available for the lungs.

In low output cardiac failure the diminution in the various divisions of lung volume is in direct relation to the degree of failure.

We are indebted to Professor Lancelot Hogben, F.R.S., for placing the facilities of his department at our disposal to Miss Gwenda Griffith and Mr. A. C. Pincock for invaluable technical assistance, to Mr. T. F. Dee for reproduction of the figure and to Imperial Chemical Industries for a grant towards the expenses of the investigation.

\section{REFERENCES}

Altschule, M. D., Zamcheck, N., and Iglauer, A. (1943). J. clin. Invest., 22, 805.

Binger, C. A. L. (1923). J. exp. Med., 38, 445.

Borden, C. W., Ebert, R. V., Wilson, R. H., and Wells, H. S. (1949). J. clin. Invest., $28,1138$.

Brittingham, H. H., and White, P. D. (1922). J. Amer. med. Ass., 79, 1901.

Drinker, C. K., Peabody, F. W., and Blumgart, H. L. (1922). J. exp. Med., 35, 77.

Ebert, R. V., Borden, C. W., Wells, H. S., and Wilson, R. H. (1949). J. clin. Invest., $28,1134$.

Lundsgaard, C. (1923). J. Amer. med. Ass., 80, 163.

Mack, I., Grossman, M., and Katz, L. N. (1947). Federation. Proc., 6, 161.

McClure, C. W., and Peabody, F. W. (1917). J. Amer. med. Ass., 69, 1954.

McMichael, J. (1939). Clin. Sci., 4, 167.

Meakins, J. C., and Christie, R. V. (1929). Ann. intern. Med., 3, 423.

Meneely, G. R., and Kaltreider, N. L. (1943). J. clin. Invest., 22, 521.

Peabody, F. W., and Wentworth, J. A. (1917). Arch. intern. Med., 20, 443.

Pearce, R. G. (1917). J. Amer. med. Ass., 69, 1954.

Peters, J. B., and Barr, D. P. (1921). Amer. J. Physiol., 54, 335.

Whitfield, A. G. W., Waterhouse, J. A. H., and Arnott, W. M., (1950a). Brit. J. Soc. Med., $4,1$.

$\longrightarrow$ - $-(1950 b)$. Ibid., 4, 86. 